\title{
The Red Web: The Struggle Between Russia's Digital Dictators and the New Online Revolutionaries. By Andrei Soldatov and Irina Borogan. New York, N.Y.: PublicAffairs, 2015
}

Edward M. Roche

Columbia Institute for Tele-Information

Follow this and additional works at: https://digitalcommons.usf.edu/jss

pp. 122

\section{Recommended Citation}

Roche, Edward M.. "The Red Web: The Struggle Between Russia's Digital Dictators and the New Online Revolutionaries. By Andrei Soldatov and Irina Borogan. New York, N.Y.: PublicAffairs, 2015." Journal of Strategic Security 8, no. 4 (2015) : 122.

DOI: http://dx.doi.org/10.5038/1944-0472.8.4.1497

Available at: https://digitalcommons.usf.edu/jss/vol8/iss4/11

This Book Review is brought to you for free and open access by the Open Access Journals at Digital Commons @ University of South Florida. It has been accepted for inclusion in Journal of Strategic Security by an authorized editor of Digital Commons @ University of South Florida. For more information, please contact digitalcommons@usf.edu. 
The Red Web: The Struggle Between Russia's Digital Dictators and the New Online Revolutionaries. By Andrei Soldatov and Irina Borogan. New York, N.Y.: PublicAffairs, 2015 


\section{The Red Web: The Struggle Between Russia's Digital Dictators and the New Online Revolutionaries. By Andrei Soldatov and Irina Borogan. New York, N.Y.: PublicAffairs, 2015. ISBN 978-1- 61039-573-1. Photographs. Notes. Sources cited. Index. Pp. xi, 370. \$27.99.}

The Red Web is a history of Internet governance and SIGINT in Russia covering 1950 until 2015. Having departed Russia for Berkeley, California, the authors, Andrew Soldatov and Irina Borogan founded Agentura.ru, a website that reveals many secrets regarding surveillance and governmentpress relations in today's Russian Federation. Their extensive news work in Russia put them in a cat's bird position to record the epic struggle between internet freedom and a free press against the government forces calling for more security and surveillance. The Red $W e b$ is a significant contribution to the literature on freedom of communications, but also provides priceless insights into how the Russian government developed technologies for eavesdropping and monitoring of internet communications, all of them. It is surprising that a book containing this level of detail on such a highly sensitive subject involving Russian national security ever was published.

The book opens in 1950 detailing the activities at a special sharashka, a prison camp that held scientists tasked with developing surveillance technology. It ends up describing the MSK-IX Internet exchange point located at phone station M9 in Moscow. Here as in all other internet switching centers across Russia, SORM boxes intercept all communications for the Federalnaya Sluzhba Bezopasnosti or FSB. SORM is an acronym for Systema OperativnoRozysknikh Meropriatiy or System of Operative Search measures.

The work chronicles development of early SORM technologies, and growth of the Russian internet which grew rapidly leading up to the dissolution of the USSR. In the new Russia, there was a short period of relative internet freedom which was curtailed slowly but conclusively by the government under President Putin. It is the detailed technical history of SORM development, including personal details of the major designers and engineers as well as the operational challenges, that is a strength of this book. This story is told along with the parallel transformation in the legal and political environment, leading up to the Snowdon revelations, and the capitulation of all Russian ISPs. As a side note, it was surprising to learn that Alexander Solzhenitsyn worked in a few of these secret laboratories before being sent off to the gulag.

The Red Web is a crucial read for anyone interested in Russia or in how communications intelligence might be used in the new world of social media.

Edward M. Roche, Henley-Putnam University 